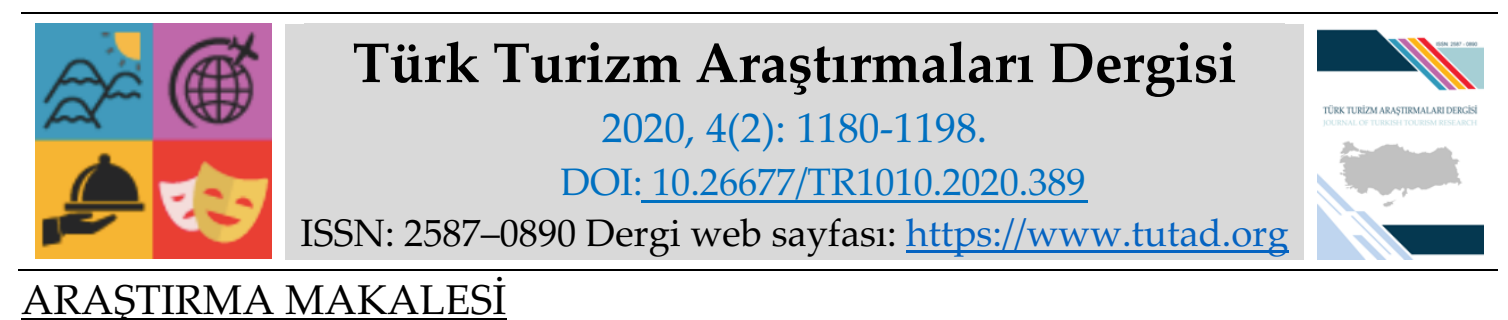

ARAŞTIRMA MAKALESI

\title{
Turizm Fakültesi Akademisyenlerinin Sağlık Turizmine Yönelik Farkındalığının Değerlendirilmesi
}

Büşra GÖKMEN, Necmettin Erbakan Üniversitesi, Sosyal Bilimler Enstitüsü, Konya, e-posta: gokmenbsra@gmail.com ORCID: https://orcid.org/0000-0002-7445-8861

Dr. Öğr. Üyesi Mustafa Cüneyt ŞAPCILAR, Necmettin Erbakan Üniversitesi, Turizm Fakültesi, Konya, e-posta: mustafcuneyt@gmail.com

ORCID: https://orcid.org/0000-0002-6098-8490

Prof. Dr. Ahmet BÜYÜKŞALVARCI, Necmettin Erbakan Üniversitesi, Turizm Fakültesi, Konya, e-posta: ahmetbuyuksalvarci@gmail.com

ORCID: https://orcid.org/0000-0001-7207-3987

Öz

Sağlık turizmi sağladığı ekonomik katkılardan dolayı dünya genelinde kabul gören önemli alternatif turizm türlerinden birisidir. Sektöre getirilen uluslararası standartlar gelişmiş ülkelerin yanı sıra gelişmekte olan ülkelerin de kalite ve nitelik olarak gelişmesini zorunlu hale getirmiştir. Bu sebeple plan, politika ve istihdam gibi alanların etkilenmesi başta turizm sektörünün bütün paydaşlarını ilgilendirmektedir. Bu çalışmada turizm paydaşları arasında önemli bir yeri bulunan turizm akademisyenlerinin sağlık turizmine yönelik farkındalıklarının değerlendirilmesi amaçlanmıştır. Amaç doğrultusunda birincil veri elde etmek için Ankara ve Konya ilinde bulunan 3 üniversitenin turizm fakültelerinde görevli 19 akademisyen ile görüşmeler gerçekleştirilmiştir. Elde edilen bulgulara göre akademisyenler, Türkiye'de sağlık turizmi potansiyelinin var olduğunu ve özellikle medikal turizmde avantajlı konumda bulunulduğunu ancak başta tanıtım olmak üzere pazarlama faaliyetlerinde yetersizlik olduğunu vurgulamışlardır. Çalışma sonucuna göre akademisyenlerin sağlık turizminde genel bilgilere sahip olduğu ancak sağlık kuruluşlarının yapmış olduğu uygulamalar hakkında derinlemesine bilgi sahibi olmadıkları belirlenmiştir.

Anahtar Kelimeler: Sağlık Turizmi, Termal Turizm, SPA-Wellness Turizmi, Medikal Turizm, Turizm Fakülteleri.

Makale Gönderme Tarihi: 23.02.2020

Makale Kabul Tarihi: 11.04 .2020

Önerilen Atıf:

Gökmen, B., Şapcılar, M. C. ve Büyükşalvarcı, A. (2020). Turizm Fakültesi Akademisyenlerinin Sağlık Turizmine Yönelik Farkındalığının Değerlendirilmesi, Türk Turizm Araştırmaları Dergisi, 4(2): 1180-1198.

(C) 2020 Türk Turizm Araştırmaları Dergisi. 


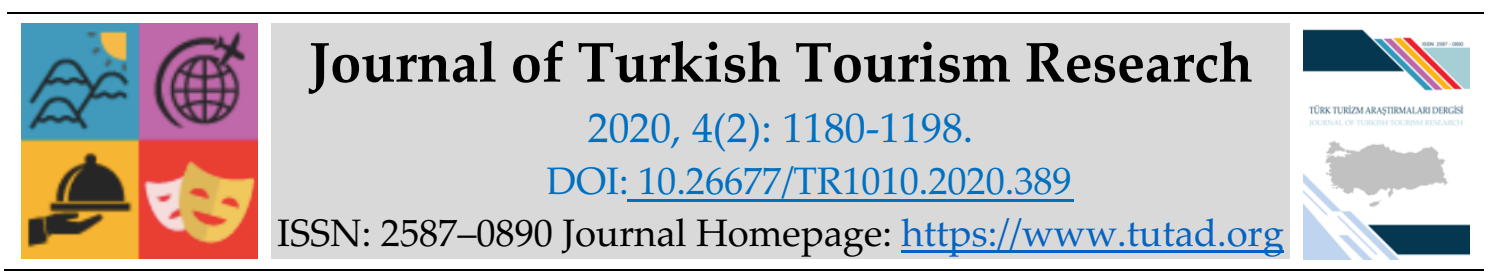

RESEARCH PAPER

\title{
Evaluation of the Awareness of Tourism Faculty Academicians towards Health Tourism
}

Büşra GÖKMEN, Necmettin Erbakan University, Social Sciences Institute, Konya, e-mail: gokmenbsra@gmail.com

ORCID: https://orcid.org/0000-0002-7445-8861

Assistant Prof. Dr. Mustafa Cüneyt ŞAPCILAR, Necmettin Erbakan University, Faculty of Tourism, Konya, e-mail: mustafcuneyt@gmail.com

ORCID: https://orcid.org/0000-0002-6098-8490

Prof. Dr. Ahmet BÜYÜKŞALVARCI, Necmettin Erbakan University, Faculty of Tourism, Konya, e-mail: ahmetbuyuksalvarci@gmail.com

ORCID: https://orcid.org/0000-0001-7207-3987

\begin{abstract}
Health tourism is one of the important alternative tourism types due to the economic contributions. The international standards introduced have made it obligatory for developing countries to develop in quality and character as well as in developed countries. These developments not only affect all stakeholders of the tourism sector but also affect areas such as plan, policy and employment. In this study, it is aimed to evaluate the awareness of tourism academicians who have an important position among the tourism stakeholders towards health tourism. In this context, in order to obtain primary data, interviews were made with 19 academicians working in the tourism faculties of 3 universities in Ankara and Konya. According to the findings obtained, academicians stated that the potential of health tourism exists and Turkey has an advantageous position especially in medical tourism, however, they emphasized that there was inadequacy in marketing activities and publicity. According to the results of the study, it has been determined that academics have general knowledge in health tourism, but they do not have in-depth knowledge about the practices of health institutions.
\end{abstract}

Keywords: Health Tourism, Thermal Tourism, SPA-Wellness Tourism, Medical Tourism, Tourism Faculties.

Received: 23.02 .2020

Accepted: 11.04 .2020

Suggested Citation:

Gökmen, B., Şapcilar, M. C. and Büyükşalvarcı, A. (2020). Evaluation of the Awareness of Tourism Faculty Academicians towards Health Tourism, Journal of Turkish Tourism Research, 4(2): 1180-1198.

(C) 2020 Türk Turizm Araştırmaları Dergisi. 


\section{Gíriş}

Geçmişte insanlar, geleneksel tedavi yöntemleriyle sağlık hizmeti almak için mecburi seyahate çıkarken günümüzde modern sağlık hizmetlerine ulaşmak için boş vakitlerini seyahate ayırmaktadırlar (Yazan, Girgin ve Karadă̆, 2017:196). Yapılan arkeolojik değerlendirmeler neticesinde köklerinin antik çağlara dayandığı sağlık hizmetleri; Sümerler, Eski Mısırlılar, Eski Çin medeniyeti, Eski Hint uygarlı̆̆ı, Endülüs Emevi Devleti gibi kadim medeniyetlerde kendini farklı tedavi yöntemleriyle ortaya koyan bir kavramdır (Özcan ve Aydın, 2015:70-72). Günümüzde ise insanların tedavi görmek üzerine bakış açlarındaki değişme, sağlık hizmetlerinde değişimin devam ettiğinin bir göstergesidir. Sağlık ihtiyaçlarının karşılanmasında yaşanan hareketlilik sağlık turizmi sektörünün doğmasına yol açmıştır (Aba, Gümüş ve Çakır, 2019:94). Sağlık turizmi, bir yıldan uzun olmamak kaydıyla sağlık odaklı hizmetler sunan tatil yerlerine ve kaplicalara yapılan seyahatleri kapsamaktadır (Breitrück ve Nunn, 2011:58). İnsanların fiziksel, zihinsel, sosyal ve ekolojik risk faktörlerine karşı korunmak ve sağlık refah seviyesini yükseltmek istemesi sağlık turizmi talebini artırmaktadır (Rieger, 2013:59-65). Globalleşme ile birlikte ülkeler arasında etkileşimin artması, iletişim ve ulaşım imkânlarının gelişmesi (Tontuş, 2018:68), cinsiyet değişimi gibi Türkiye'de yasal olmayan eylemlerin bazı ülkelerde yasal olması ve insanların seyahat özgürlüklerinin kolaylaşması (Çimen, 2018:108), gibi avantajların doğması sağlık turizminin gelişmesine yol açmıştır.

$\mathrm{Bu}$ çalışmanın amacı, turizm paydaşları arasında değerlendirilen turizm akademisyenlerinin, hızla gelişen sağlık turizmine yönelik farkındalık seviyelerini belirlemek ve akademisyenlerin paydaşlar olarak sürece dair bakış açılarını ortaya koymak olarak belirlenmiştir.

\section{SAĞLIK TURİZMI}

Sağlık turizmi üzerine kesin bir tanımlama bulunmamasına rağmen (García-Altés, 2005:262), "bireylerin koruyucu, tedavi edici, rehabilite edici ve sağlı̆̆ geliştirici hizmetler almak amacıyla yerleşik olduğu ülke dışında bir ülkeye yaptığı ziyaretler" olarak tanımlamak mümkündür (Zengingönül vd., 2012:4). Farklı ülkelerdeki akademik çevre ve kurumlarda farklı anlamlar ifade eden sağlık turizmi, talep ve arz açısından değerlendirilmeye alınarak değişik tanımlamalarla ifade edilmiştir (Temizkan, 2015:14-16). Literatürde bir kavram kargaşasının bulunmasından ötürü bazen "Medikal Turizm" olarak da adlandırılan sağlık turizmi üç başlık altında çeşitlendirilmiştir. Bu başlıklar, termal turizm, SPA-wellness turizm ve medikal turizmdir (Aydın, 2012:93). Bu kapsamda termal turizm, termomineral su banyosu, içme, çamur banyosu gibi çeşitli etkinliklerin yanında hem fizik tedavi, rehabilitasyon, diyet gibi tedavi türlerinin birleştirilmesiyle oluşan tedavi hem de termal sularda rekreasyon ve eğlence ile oluşan sağlık turizm çeşididir (Çılgınoğlu, 2018:26-29). SPA-Wellness turizm, su ve çeşitli aromatik kürler kullanılarak vücudun ağrı ve acılarının azaltılması ve dinlenmesi amacıyla profesyonel ekipler eşliğinde uygulanan, verilen SPA hizmet türüne göre yedi sınıflamaya tabi tutulan bir tedavi yöntemidir (Gülmez, 2012:36). Medikal turizm ise, belirli bir hastalığ olan turistlere tedavi amaçlı sağlık kurum ve kuruluşları tarafından planlı olarak sunulan hizmetlerdir (Ataman vd., 2017:32). Küreselleşmenin de etkisiyle hızla gelişen sağlık turizmi (Bayar, 2019:2), alt sektörlerindeki çeşitlilik ile varlığını ortaya koymaktadır.

\section{Sağlık Turizminin Gelişimi}

Eski Mısır'da kadınların kozmetik kullanımı, Çin'de tıbbi uygulamaların varlığı, Yunanlılar, Romalılar ve Osmanlılarda hamam kültürü, Asya ve Orta Doğu'da meditasyon, bitkisel ilaçların 
yapımı insanların şifa bulmak ve ruhsal çözümlere kavuşma isteğinin MÖ 5000'lerden günümüze kadar uzandığının bir göstergesidir (Koncul, 2012:529). Bu kapsamda Yunan tanrısı Asklepios onuruna inşa edilen Asklepios Tapınaklarında mistik ve şifa ritüellerinin düzenlenmesi, Kahire'de Mansuri Hastanesinin inşa edilmesi, Japonya'da "onsen" (sıcak su kaplıcalarının) yaygınlığı, Hindistan'da Budist hac ziyaretleri ve meditasyon amaciyla yapılan yoga, Avrupa'da Sulis su tanrıçasından türetilen Bath veya Aquae Sulis gibi önemli kaplıcalar sağlığa verilen öneme örnek gösterilebilmektedir (Ross, 2001:87-92). Eski çağlarda insanların şifa ve iyilik bulmak amacıyla kutsal saydıkları insan ve mekanları ziyareti, soyluların ve savaşlarda yaralanan askerlerin sağlık amacıyla sıcak su kaynaklarını kullanması, sağlık ve şifa sunan bölgelere doğru yönelmelere neden olmuştur. Kaplıca turizmi ya da termal turizm olarak başlayan sağllk ve turizm ilişkisi 1980'li yılların başında yeni bir boyuta dönüşmüştür. Bu yıllardan itibaren "sağlık" üzerine yeni bir fikir akımının doğması başta oteller olmak üzere birçok tesiste sağllk kulüpleri, spor, deniz terapileri, diyet ve fizyoterapiler gibi pek çok tedavi alanları ortaya çıkarmıştır (Becheri, 1989:16). İlk çağlarda yaşanan şifa hareketliliği sağlık turizminin ilk dalgasını oluştururken, az gelişmiş ülkelerde teknolojik yetersizlik, yerel sağlık hizmetlerinin kötü altyapısı, nitelikli personel eksikliğinden ötürü bu ülkelerin insanlarının kendi ülkelerinde bulunmayan tedavi hizmetlerini almak için gelişmiş ülkeleri ziyarete gitmesi geleneksel medikal turizm olarak adlandırılan ikinci dalgayı oluşturmuştur. Gelişmekte olan ülkelerin sağlık kurumlarında yenilik başlatması, yeni teknik ve uygun maliyet sağlayan teknolojik gelişmeler, gelişmiş ülkelerde sınırlı veya eksik sigorta temini ve kısıtlı sağlık hizmetleri, gelişmiş ülkelerden gelişmekte olan ülkelere doğru yeni hareket eğilimine yol açmıştır. Böylelikle "yeni tıbbi turizm" olarak nitelenen üçüncü dalga başlamıştır (Aydın ve Karamehmet, 2017:16-17; Baş, 2017:57; Tür, 2015:4-5). Sağlık turizminde yaşanan bu dalgalanmalar, gelecekte sağlık turizminin alacağı rolü anlamak açısından önemli görülmektedir.

Son yıllarda yaşlı nüfusun toplam nüfus içindeki payının artması, gelişmiş ülkelerde sağlık hizmetlerinde ortalama sağlık harcamalarının artmasında yol açmıştır (Uçak, 2016:2). Sağlıkta meydana gelen patlamanın etkisiyle medikal sağlı̆ın büyümesinin yeni ekonomik güç olduğu tahmin edilmektedir. Çünkü toplumdaki demografik değişim ve yaşam beklentisi sağlikta para harcama eğilimini artırmaktadır ve bu eğilim turizm sektörüne katkı sağlamaktadır (Hofer, Honegger ve Hubeli, 2012:75). Sağlık turizmi, ekonomik yönden hem döviz kazandırıcı işlem olarak hem de hizmetler sektörü ile olan bağlantısıyla ikincil ve üçüncül sektörlere yayılarak ekonomik bir dalga oluşturmaktadır (Özkurt, 2007:127-128). Bu bağlamda sağlık turizmi, sağlıklı yaşam talebine bağlı olarak dünyanın milyar dolarlık hızlı gelişen sektörlerinden biridir (Yavuz, 2017:248). Bu ekonomik gelişim beraberinde belirli standartları da zorunlu hale getirmiştir. Uluslararası akreditasyon sistemleri ise bu zorunluluğun belirgin özelliğidir (Smith ve Forgione, 2007:25-26). 1994 yılında Amerika'da Joint Commission International (JCI) yapılandırması, İngiltere'de Quantum Health Automation (QHA) Trend sistemi, Avustralya'da Australian Council on HealthCare Standarts (ACHS) kuruluşu sağlık tesislerinin öncelemesi gereken akreditasyon uygulamalarından birkaçıdır (www.saturk.gov.tr). Ayrıca modern sağlık tesislerinin yapılması, tıbbi bakımda kalitenin yükseltilmesi, sağlık hizmeti sunan personelin eğitimine odaklanılması ve sosyal bir hak olan sağlık hakkının sağlanmasıyla halk sağlığı sistemleri gelişme sağlayarak toplumda olumlu bir etki yaratmaktadır (Dedeoğlu, 2018:90-91).

\section{Dünya'da Sağlık Turizmi}

Küresel sağlık harcamaları, 2012-2016 döneminde yıllık \%1,3 artış gösterirken 2017-2021 döneminde yıllık \%4,1 oranında artması tahmin edilmektedir (Deloitte, 2018:5). Uzun vadeli bakım harcamalarının son birkaç yılda artmış olması, hızlı teknolojik gelişmeler ve kentsel 
yaşamın sebep olduğu kronik rahatsızlıklar vs. dünya sağlık turizminin katlanarak artmasına yol açmıştır (World Tourism Organization and European Travel Commission, 2018). Küresel sağlık hareketliliğinde, Amerikalı turistlerin \%45'inin ve Avrupalı turistlerin \%39'unun Asya ülkelerini tercih etmesi (Batı Akdeniz Kalkınma Ajansı, 2013:11), Asya kıtasının sağlık turizminde öncü kıta olmasına yol açmaktadır. Asya sağlık turizm pazarında; Singapur ve Hindistan medikal turizmi, Tayland ve Malezya sağlık SPA turizmi, Japonya ise kaplıcaları ile yer almaktadır. Hintli doktorların ABD ve İngiltere insanı tarafından tanınmış olması, Hindistan Hükümetinin sağlık turizm harcamalarına destek vermesi, daha iyi sağlık altyapısı için yapılan çalışmalar ve elde edilen maliyet avantajı (Göçer ve Aydın, 2016:782) başta ABD olmak üzere İngiltere, Avrupa ve Ortadoğu'dan hastalar çekmek için yapılan iyileştirmelerdendir (Cochrane, 2008:379-387). Malezya'da 2009 yılında Malezya Sağlık Seyahat Konseyi (MHTC)'nin kuruluşu ile JCI tarafından akredite edilen sağlık tesislerinin sayısında artış yine ABD, İngiltere, Bangladeş, BAE ve Çin'de bulunan hastaları cezbetmektedir (Loh, 2014:765). Singapur Hükümetinin turizm endüstrisini geliştirmek için Singapur Turizm Kurulu aracılı̆̆ıyla "Benzersiz Singapur" kampanyası başlatması, Singapur'un tıbbi olarak turizm merkezlerinden bir tanesi olmasında önemli rol oynamıştır (Lee, 2010:486-488). Medical Tourism Magazine (2019), tarafından yayınlanan raporda medikal turizm destinasyonunda ilk beş ülke sırasıyla; Hindistan, Kolombiya, Meksika, Kanada ve Dominik Cumhuriyeti'dir.

Dünya sağlık turizm hareketliliği Avrupa Birliği açısından değerlendirildiğinde 2014 yılında toplam turistlerin sayısının \%4.3'ünü sağlık turistleri oluşturmaktadır (European Parliament, 2017) ve popüler sağlık turizm hizmetleri; vücut bakımı, spor ve fitnes, sauna, yoga ve meditasyon, beslenme ve detoks geleneksel sağlık turizmi, beden-zihin-ruh bütünsel programları, sağlık beslenme, kişisel gelişim, yaşam kalitesi vd. hakkında öğrenme programları, triatlon gibi fiziksel zorluklar popüler yeni jenerasyon programlarıdır. Medikal turizm ise kozmetik cerrahi, diş hekimliği, ortopedik cerrahi, obezite ve tüp bebek zorlukları, oftalmik cerrahi olarak sıralanmaktadır (Blazevic, 2016:92). Macaristan, sağlık turizm açısından sunduğu hizmet ve tedavileriyle "diş başkenti" olarak nitelenirken dünya pazarında önemli bir konum elde etmektedir (Jònàs-Berki vd., 2015:603).

\section{Türkiye'de Sağlık Turizmi}

Türkiye'de sağlık turizmi, sağlık kuruluşlarından tedavi amaçlı faydalanma üzerine yapılanmıştır (Özata, Asilkan, Çankaya ve Suzuk, 2018:4613). Türkiye dünya sağlık turizminde termal turizm, SPA ve medikal turizm ile önemli bir potansiyele sahiptir (Aksu, Şeker ve Unur, 2017:525-527). Ayrıca Türkiye ulaşım imkânlarında kolaylık, coğrafik konumu, elverişli iklim şartları (Yardan, Dikmetaş, Us ve Yabana, 2014:33) ve zengin termal kaynakları, uluslararası düzeyde akredite hastaneleri ve sağlık tesisleri (Baysal, 2016:252-255), sağlik hizmeti sunumunda yetkin hekimleri ve destekleyici diğer kaynakları ile önemli bir sağlık turizmi destinasyonudur (Öztürk ve Bayat, 2011:137). Türkiye' de sağlık hizmetlerinin diğer ülkelere göre ucuz olması fiyat avantajı doğururken, hastanelerde yatak kapasitelerin ve hekim kalitesinin yüksek olması (Sülkü, 2017:109), sağlık hizmeti sunan personelin başta yabancı dil olmak üzere gerekli yeterlilikleri sağlamasına yönelik eğitimlerin gerçekleştirilmesi, sağlık turizmini desteklemek amacıyla gerekli teşkilatlanmanın sağlanması (Altın, Bektaş, Antep ve İrban, 2012:158-159), dünya sağlık turizm pastasından pay alma fırsatı oluşturmaktadır.

Türkiye turizminde $3 S$ (Sea, Sun, Sand) talebine "Surgery S" nin eklenmesi (Buzcu ve Birdir, 2019:316) medikal turizmin gelişim göstermesine örnek gösterilebilmektedir. Medikal turizmde, son 20 yıllık süreçte devlet destekli bir ilerleme yakalanmıştır (Barca, Akdeve ve Balay, 2013:6971). Medikal turizmi kapsamında Türkiye'de yapılan tedaviler; organ nakilleri, kalp, damar, göz 
ve diş tedavileri, estetik ve plastik cerrrahi ameliyatları, saç nakli, tüp bebek tedavileri olarak siralanabilmektedir (Arslan, 2018:27-29; Şahbaz, Akdu ve Akdu, 2012:277; Görener, 2016:160). Ayrıca, Avrupa ülkelerine göre hesaplı implant tedavileri, estetik operasyonlar, göğüs ve karın ameliyatları (Öncü, Çatı ve Yalman, 2016:49-50) Türkiye'nin tedavi amacıyla tercih edilme sebepleri arasında siralanabilmektedir.

Türkiye, sağlık alanında mevcut coğrafi konumunun yanında Müslüman bir ülke olması, son yıllarda Avrupa Birliği ile olan yakınlığın artması (Edinsel ve Adıgüzel, 2014:177), teknolojiye sahip olması, sağlık hizmetlerinin Avrupa ülkelerine kıyasla hem ucuz hem de kaliteli olması gibi güçlü yönlere sahiptir. Bu yönleriyle Türkiye, sağlık turizmi kapsamında bir çıkış trendi yakalayarak dünya sağlık turizmi sunan ülkeler sıralamasında üst sıralara yükselebileceği düşünülmektedir (Akbolat ve Deniz, 2017:128-129).

Türkiye, sağlıkta iyileşme sağlamak amacıyla sağlık hizmetlerinin sunumunda dönüşüme giderek 2003 yılında "sağlıkta dönüşüm programı" çerçevesinde bir program başlatmıştır. Ancak sağlık turizmi ve turist sağlığı alanları 2007 yılında programa dâhil edilmiştir (Şahin ve Şahin, 2018:292). Yine sağlık turizmi hizmetlerinin denetiminde merkezileşme sağlamak için Temel Sağlık Hizmetleri Genel Müdürlüğü'nün 31 Mart 2010 tarih ve 18529 sayılı onayı ile Sağlık Turizmi Birimi kurulmuştur (Acar ve Turan, 2016:24). Ancak sağlık turizminin yeni bir yatırım alanı olarak resmi belgelere girişi 2014-2018 yıllarını kapsayan 10. Kalkınma Planı döneminde olmuştur. Bu kapsamda planda belirlenen hedefler doğrultusunda Sağlık Turizm Koordinasyon Kurulu (SATURK)'un kurulacağı ve bu kurul içinde Sağlık Bakanlığı yanında Kültür ve Turizm Bakanlığı, Ekonomi Bakanlığı, Kalkınma Bakanlığı, Aile ve Sosyal Politikalar Bakanlığı, Türkiye Seyahat Acentaları Birliği (TURSAB), Türk İşbirliği ve Koordinasyon Ajansı Başkanlığı (TIKA), Yükseköğretim Kurulu (YÖK) ve diğer aracı kuruluşların dâhil edileceği belirtilmiştir (Basa, 2017:276-277). Ayrıca sağlık ve termal turizminde başta rekabet edebilirliği artırmak ve bölgesel destinasyonu geliştirmek amacıyla 2006-2023 Eylem Planı kapsamında Troya, Frigya ve Afrodisya Kültür ve Turizm Koruma ve Geliştirme Bölgelerinde ana tema termal turizm olarak belirlenmiştir (Tütüncü, Kiremitçi ve Çalışkan, 2011:91). Yine 2012 yılında yayınlanan "2012/4 Sayılı Döviz Kazandırıcı Hizmet Ticaretinin Desteklenmesi Hakkında Tebliğ" sunulan sağlık hizmetlerinin tutundurulması için atılan adımlardan biridir (Aydın ve Aydın, 2015:11). Ayrıca 2023 Türkiye Turizm Stratejisi ile sağllk teknolojisinde gelişme kaydedilmesi, şehir hastanelerinin inşası, termal turizmde büyümeyi gerçekleştirecek iyileştirmeler yapılması hedeflenmiştir (Uygun ve Ekiz, 2016:22-24). Sağllk turizminde önemli yeri olan Joint Commission International (JCI) çalışmaları ise 663 sayılı Kanun Hükmünde Kararname ile Sağlık Bakanlığının görevleri arasında yer alması ile başlamış ve ilk ulusal bağımsız kuruluş olan Türkiye Sağlık Bakım Kalitesi ve Akreditasyonu Enstitü (TÜSKA) kuruluşu ile devam etmiştir (Yorulmaz, 2019:352).

Akreditasyon, hastanenin belirlenmiş şartlara uygun olarak hizmet sunumu gerçekleştirebildiği ve bu hizmetin denetlendiği bir sistemdir (Altın vd., 2012:161). Bu kapsamda, sağlık turizminde önemli bir kriter olan uluslararası hastane akreditasyonu JCI (Yiğit, 2016:114) akreditasyonuna sahip kuruluş sayısı Türkiye'de 48 iken, sağlık bakanlığı tarafından belgelendirilmiş toplam sağlık turizm belgeli kuruluş sayısı 801 adettir (www.saglik.gov.tr).

Tablo 1. Sağlık Turizmi Akreditesi Olan Kuruluş Sayısı, 2019

\begin{tabular}{|c|c|c|c|c|}
\hline $\begin{array}{c}\text { Aracı } \\
\text { Kuruluşlar }\end{array}$ & $\begin{array}{c}\text { Kamu Sağlık } \\
\text { Tesisi }\end{array}$ & $\begin{array}{c}\text { Kamu } \\
\text { Üniversitesi } \\
\text { Hastanesi }\end{array}$ & $\begin{array}{c}\text { Vakıf } \\
\text { Üniversitesi } \\
\text { Hastanesi }\end{array}$ & $\begin{array}{c}\text { Özel Sağlık } \\
\text { Tesisi }\end{array}$ \\
\hline 77 & 108 & 25 & 23 & 568 \\
\hline
\end{tabular}

Kaynak: www.saglikturizmi.saglik.gov.tr 
Tablo 2'de seçilmiş bazı ülkelerde medikal turizm altında gerçekleşen operasyonların fiyatları verilmiştir. Amerika ve Birleşik Krallık gibi eğitim ve refah seviyesi yüksek gelişmiş ülkelerde fiyat yüksekliği dikkat çekmektedir.

Tablo 2. Seçilen Ülkelerde Medikal Turizm 2018 Fiyatları (\$)

\begin{tabular}{|l|c|c|c|c|c|c|c|c|c|}
\hline & Anjiyoplasti & $\begin{array}{c}\text { Kalp Valfinin } \\
\text { Değiștirilmesi }\end{array}$ & $\begin{array}{c}\text { Kalça } \\
\text { Protezi }\end{array}$ & $\begin{array}{c}\text { Diş } \\
\text { Implant1 }\end{array}$ & $\begin{array}{c}\text { Mide } \\
\text { Paypası }\end{array}$ & $\begin{array}{c}\text { Yüz } \\
\text { Germe }\end{array}$ & $\begin{array}{c}\text { Katarakt } \\
\text { Ameliyatı }\end{array}$ & $\begin{array}{c}\text { Tüp } \\
\text { Bebek }\end{array}$ & $\begin{array}{c}\text { Diz } \\
\text { Protezi }\end{array}$ \\
\hline Kolombiya & 7.100 & 10.450 & 8.400 & 1.200 & 12.200 & 4.000 & 1.600 & 5.450 & 7.200 \\
\hline Kosta Rika & 13.800 & 30.000 & 13.600 & 800 & 12.900 & 4.500 & 1.700 & --- & 12.500 \\
\hline Hindistan & 5.700 & 9.500 & 7.200 & 900 & 7.000 & 3.500 & 1.500 & 2.500 & 6.600 \\
\hline İsrail & 7.500 & 28.500 & 36.000 & 1.200 & 24.000 & 6.800 & 3.700 & 5.500 & 25.000 \\
\hline Ürdün & 5.000 & 14.400 & 8.000 & 1.000 & 7.500 & 3.950 & 2.400 & 5.000 & 9.500 \\
\hline Malezya & 8,000 & 13.500 & 8.000 & 1.500 & 9.900 & 3.550 & 3.000 & 6.900 & 7.700 \\
\hline Meksika & 10.400 & 28.200 & 13.500 & 900 & 11.500 & 4.900 & 2.100 & 5.000 & 12.900 \\
\hline Polonya & 5.300 & 19.000 & 5.500 & 925 & 9.750 & 4.000 & 750 & 4.900 & 8.200 \\
\hline Singapur & 13.400 & 16.900 & 13.900 & 2.700 & 13.700 & 440 & 3.250 & $\begin{array}{c}14.90 \\
0\end{array}$ & 16.000 \\
\hline $\begin{array}{l}\text { Güney } \\
\text { Kore }\end{array}$ & 17.700 & 39.900 & 21.000 & 1.350 & 10.900 & 440 & --- & 7.900 & 17.500 \\
\hline Tayland & 4.200 & 17.200 & 17.000 & 1.720 & 16,800 & 3.950 & 1.800 & 4,100 & 14.000 \\
\hline Türkiye & $\mathbf{4 . 8 0 0}$ & $\mathbf{1 7 . 2 0 0}$ & $\mathbf{1 3 . 9 0 0}$ & $\mathbf{1 1 0 0}$ & $\mathbf{1 3 . 8 0 0}$ & $\mathbf{6 . 7 0 0}$ & $\mathbf{1 . 6 0 0}$ & $\mathbf{5 . 2 0 0}$ & $\mathbf{1 0 . 4 0 0}$ \\
\hline ABD & 28.200 & 170.000 & 40.364 & 2.500 & 25.000 & 11.000 & 3.500 & $\begin{array}{c}12.40 \\
0\end{array}$ & 35.000 \\
\hline Vietnam & ---- & --- & 9.250 & --- & ---- & 4.150 & --- & --- & 8.000 \\
\hline
\end{tabular}

Kaynak: www.medicaltourism.com

Eski bir İngiliz sömürgesi olan Hindistan gibi azgelişmiş ülkelerde medikal turizm fiyatları görece daha düşüktür. Bunun sebebi olarak ülkenin medikal turizm potansiyelini farkına erken varmaları ve düşük maliyet ile çalışmaları gösterilebilmektedir (Tablo 2).

Grafik 3. Sağllk Turisti ve Sağlık Turizmi Geliri (Bin \$)

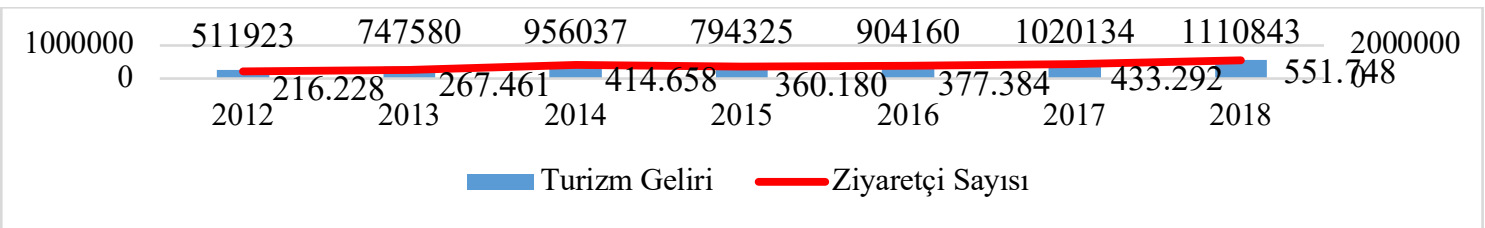

Kaynak: www.tuik.gov.tr

Sağlık hizmeti için Türkiye'yi seçen sağlık turistlerinin sayısının yıllar itibariyle arttığı ve Türkiye'ye kazandırdığı sağlık turizm gelirlerine bakıldığında yıllar itibariyle yükseliş gösterdiği ve 2018 yılında bir turistin ortalama 2.013 \$ harcama yaptığı Grafik 3'te görülmektedir. 
Grafik 4. 2018 Yılı Uluslararası Hastaların Geldiği İlk 10 Ülke

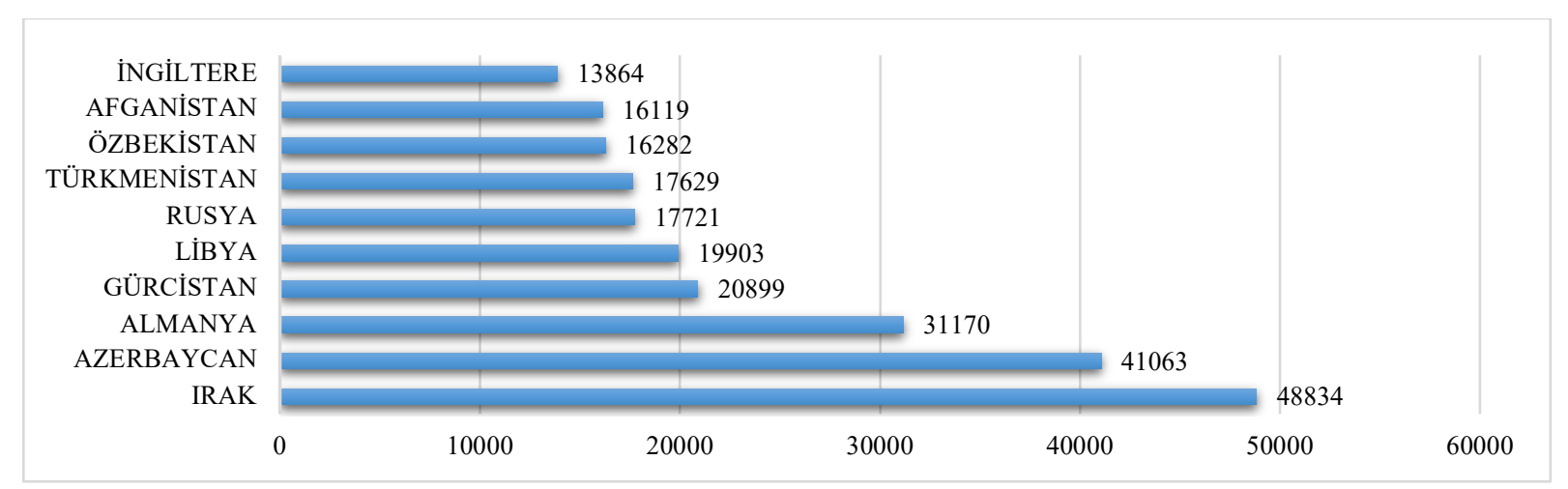

Kaynak: T.C. Sağlık Bakanlığı, 2019.

T. C. Sağlık Bakanlığı yabancı hasta takip sisteminden elde edilen sağlık turistleri verilerine göre, Türkiye'ye sağlık hizmeti almak için gelen turistlerin çoğunluğunun komşu ülke vatandaşları olduğu görülmektedir. Ayrıca Almanya ve İngiltere'de sağlık harcamalarının maliyetlerinin yüksek olmasından dolayı Türkiye'yi tercih ettikleri düşünülmektedir.

Grafik 5. 2018 Yılı Uluslarararsı Hastaların Tercih Ettiği İlk 10 Klinik

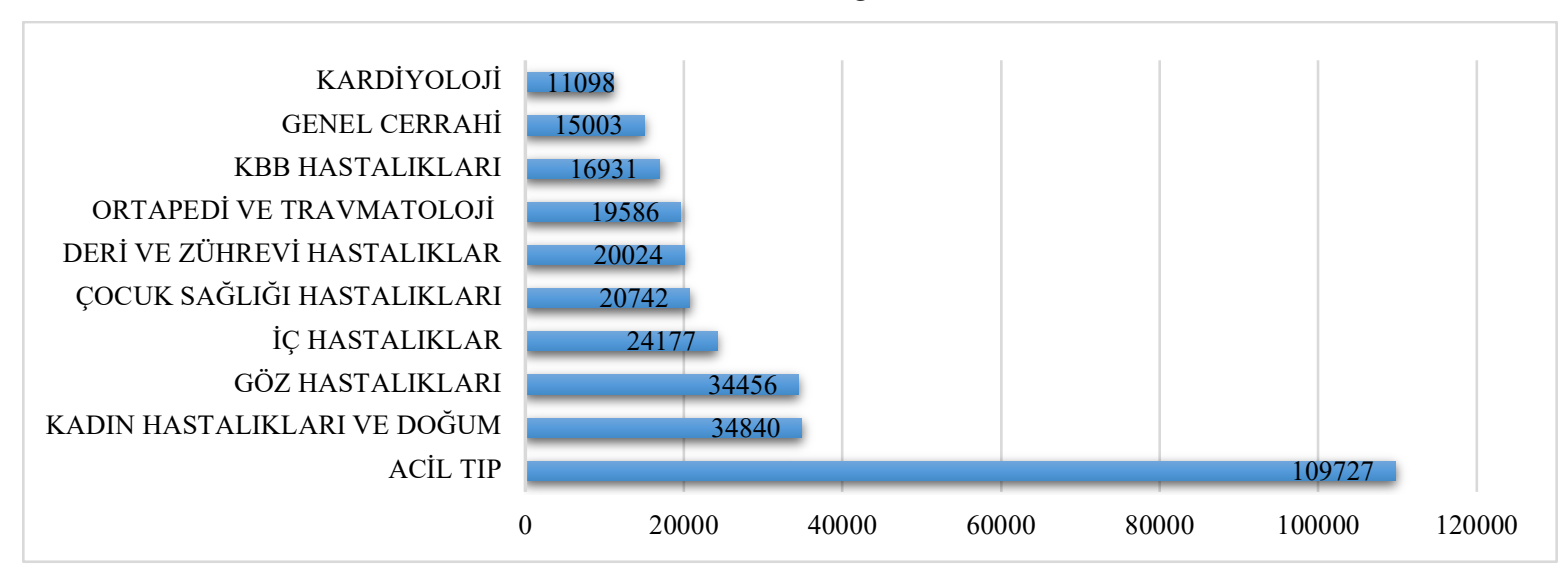

Kaynak: T.C. Sağlık Bakanlığı, 2019.

2018 yılında uluslararası hastaların en fazla tercih ettiği klinik "acil tıp" olarak kaydedilmiştir. Acil tıp kliniğinin yüksek olmasının nedeni turistin sağlığ istatistiklerinin de acil tıp istatistiğine dâhil edilmesi olarak düşünülmektedir.

Uluslararası hastaların tedavi olmak için hizmet kalitesi ve bilinirliği fazla, havayolu ile ulaşımı kolay ve sınır kapılarına yakın illeri tercih ettikleri Grafik 6.'da görülmektedir. 
Grafik 6. 2018 Yılı Uluslararası Hastaların Tercih Ettiği İlk 10 İl

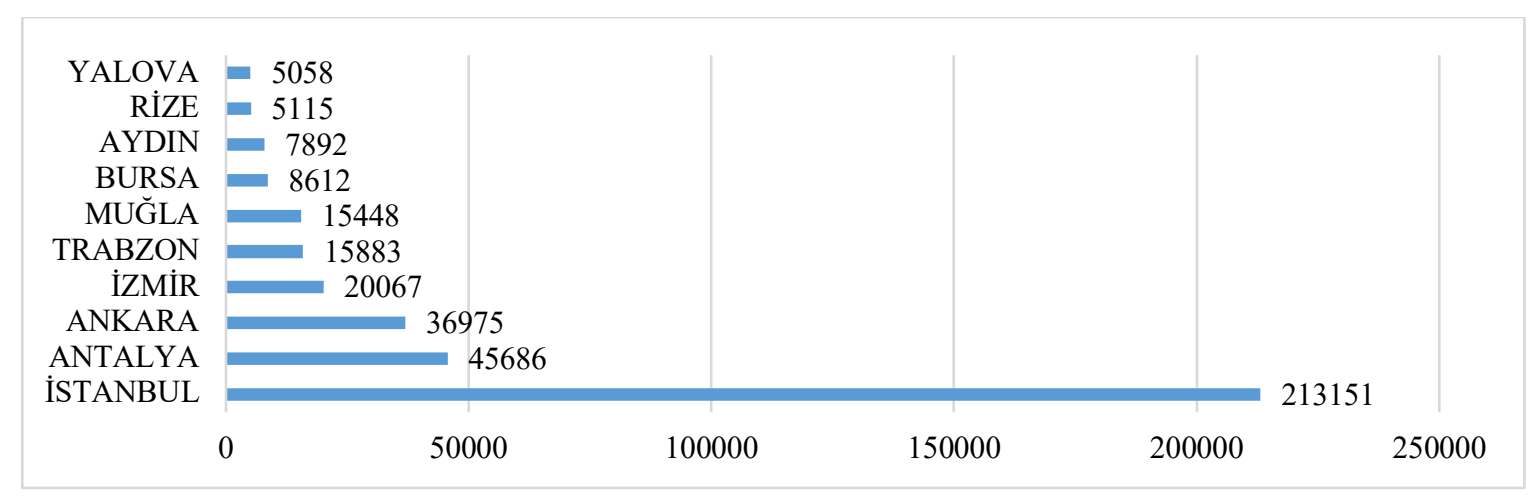

Kaynak: T.C. Sağlık Bakanlığı, 2019.

\section{YÖNTEM}

Bu çalışmada, turizm fakültelerinde görev yapan akademisyenlerin sağlık turizmine yönelik farkındalıklarının değerlendirilmesi amaçlanmıştır. Çalışma, Ankara ve Konya ilinde eğitim öğretim faaliyetine devam eden ve turizm fakültesinde aktif olarak görev yapan akademisyenleri kapsamaktadır. Çalışma için gerekli olan birincil veriler yarı yapılandırılmış görüşme tekniği ile elde edilmiştir. Bu teknikte araştırmacı önceden planladığı soruları görüşmenin akışına göre değiştirebilmesi ve kişinin yanıtlarını açması diğer görüşme tekniklerinden ayrılmaktadır (Türnüklü, 2000:547). Birincil veri elde etmek amaciyla 20.12.2019-07.01.2020 tarihleri arasında Konya ili Necmettin Erbakan Üniversitesi, Turizm Fakültesi ve Selçuk Üniversitesi, Turizm Fakültesi, Ankara ili Hacı Bayram Veli Üniversitesi, Turizm Fakültesi'ndeki görevli 19 akademisyen ile yüz yüze görüşme gerçekleştirilmiştir. Böylece sağlık turizmi üzerine çalışma konusu ayrımı yapılmaksızın turizm akademisyenlerin konu üzerindeki farkındalık seviyelerine erişilmek istenmiştir. Çalışma kapsamında öncelikle katılımcıların tanıtıcı özelliklerine yer verilmiştir. Daha sonra akademisyenlerin sağlık turizmine yönelik farkındalıklarının belirlenmesi amacıyla Canver (2015), Kızıldağ (2018) ve Altsoy (2018)'un çalışmalarında kullandığı sağlık turizmi farkındalık ve algı değerlendirme ölçeklerinden faydalanılmıştır. Buna göre akademisyenlerin sağlık turizminde etkinlik, kurumsal yeterlilikler, imaj ve kalifikasyon boyutunda farkındalık düzeyleri belirlenmeye çalışılmıştır. Görüşme sonucunda elde edilen verilerin analiz kısmında bazı katılımcıların görüşlerine yer verilerek alıntılar yapılmıştır. Çalışmada katılımcı ismi verilmeyeceğinden dolayı kodlama tekniğinden yararlanılmış ve böylece katılımcilar K1, K2...K19 olmak üzere kodlanmıştır.

Araştırmanın yapılabilirliğini sınırlandıran örneklem grubunun farklı illerde olması, ulaşım giderlerini arttırdığı için çalışmaya daha fazla üniversitenin dâhil edilememesi maliyet kısıtı; görüşmeye katılan katılımcıların vaktinin çok harcanmamasından ötürü zaman kısıtı araştırmanın sınırlılıkları olarak belirlenmiştir.

\section{BULGULAR}

Çalışma kapsamında yapılan görüşmeler sonucunda ilk önce katılımcıların tanıtıcı özelliklerini ilişkin bilgiler elde edilmiştir. Buna göre, Tablo 3'te katılımcıların cinsiyeti, yaşı, unvanı, mesleki tecrübesi, bağlı bulunan kurumu ve bu kurumdaki mesleki tecrübesine ait bilgilere yer verilmiştir. 
Tablo 3. Katılımcların Demografik Bilgileri $(\mathrm{K}=19)$

\begin{tabular}{|c|c|c|c|c|c|}
\hline & & $\mathbf{n}$ & & & n \\
\hline \multirow{2}{*}{ Cinsiyet } & Kadın & 2 & \multirow{6}{*}{$\begin{array}{l}\text { Mesleki } \\
\text { Tecrübe }\end{array}$} & 1-4 Yil & - \\
\hline & Erkek & 17 & & $5-9 Y_{11}$ & 4 \\
\hline \multirow{6}{*}{ Yaş } & $25-29$ yaş & -- & & 10-14 $Y_{11}$ & 4 \\
\hline & 30-34 yaş & 2 & & 15-19 Yil & 3 \\
\hline & $35-39$ yaş & 5 & & $20-24 Y_{11}$ & 3 \\
\hline & 40-44 yaş & 5 & & 25 Yil ve üzeri & 5 \\
\hline & $45-49$ yaş & 4 & \multirow{6}{*}{$\begin{array}{c}\text { Bağlı } \\
\text { Bulunan } \\
\text { Kurumdaki } \\
\text { Tecrübe }\end{array}$} & $1-4 Y_{11}$ & - \\
\hline & 50 ve üzeri yaş & 3 & & 5-9 Y 11 & 9 \\
\hline \multirow{5}{*}{ Unvan } & Prof. Dr. & 3 & & 10-14 Y 1 & 4 \\
\hline & Doç. Dr. & 7 & & 15-19 Y1l & 1 \\
\hline & Dr. Ögr. Üyesi & 5 & & 20-24 Y 1 & 1 \\
\hline & Dr. Ögr. Gör. & 2 & & 25 Yil ve üzeri & 4 \\
\hline & Arş. Gör. & 2 & & & \\
\hline \multirow{3}{*}{$\begin{array}{l}\text { Bağlı } \\
\text { Olunan } \\
\text { Kurum }\end{array}$} & $\begin{array}{l}\text { Necmettin Erbakan } \\
\text { Üniversitesi (NEÜ) }\end{array}$ & & \multicolumn{3}{|c|}{6} \\
\hline & $\begin{array}{l}\text { Selçuk Üniversitesi } \\
\text { (SÜ) }\end{array}$ & & \multicolumn{3}{|c|}{7} \\
\hline & $\begin{array}{c}\text { Hacı Bayram Veli } \\
\text { Üniversitesi (HBÜ) }\end{array}$ & & \multicolumn{3}{|c|}{6} \\
\hline
\end{tabular}

Tablo 3.'e göre, katılımcılar cinsiyet açısından ele alındığında "erkek" katılımcların çoğunlukta olduğu, yaş açısından değerlendirildiğinde 35-39 yaş aralığı ve 40-44 yaş aralığının ağırlıkta olduğu, unvan açısından ise "Doç. Dr. ve Dr. Ögr. Üyesi” unvanına sahip katılımcının daha fazla sayıda olduğu görülmektedir. Ayrıca bağlı bulunan kurum açısından katılımcı sayısının NEÜ 6, HBÜ'de 6 ve SÜ'de 7 kişi olduğu; mesleki tecrübe açısından bu kişilerin 5-9 yıl ve 10-14 yıl aralığında daha fazla değer aldığı; bağlı bulunan kurumdaki tecrübe açısından ise 5-9 yıl aralığının yoğunlukta olduğu sonuçlarına erişilmiştir.

Araştırma kapsamında ilk olarak akademisyenlere "Fakültenizde veya bölümünüzde sağlık turizmi ile ilgili ders veriliyor mu?" sorusu yöneltilmiştir. Bu kapsamda katılımcılar sağlık turizmine SÜ’nde alternatif turizm türleri başlığı altında yer verildiğini; HBÜ'de ise "hastane hizmetleri ve sağlık otelciliğgi" dersi altında sağlık turizminin ele alındığı belirtmiştir. NEÜ'de ise K2 ve K10 doktora derecesinde sağlık turizmi dersi verildiğini diğer katılımcılar ise fakültede veya bölümde böyle bir ders verilmediğini belirtmişlerdir. Sürdürülebilir sağlık turizmi gelişimi sağlamak için hem paydaşlar arasında işbirliğini devam ettirmek hem de uygulanacak politikaların verimliliği artırmak sağlık turizmi uzmanlarına ihtiyacı artıracaktır. Alandaki ihtiyacı gidermek için üniversitelerin sorumluluk kabul ederek sağlık turizmi eğitimi konusundaki eksikliklerini tamamlaması yerinde olacaktır. Ayrıca istihdam olanakları çoğaltılması sağlanarak ekonomik büyümenin artırılmasına da yardımcı olunabileceği düşülmektedir.

Katılımclardan Dünya sağlık turizm destinasyonunda yer alan ilk 10 ülke sıralaması istenilmiştir. Buna göre; Amerika, Almanya, Japonya, Polonya, İngiltere, Hindistan, Türkiye ve Malezya katılımcıların genel sıralaması içerisinde ağırlık kazanmıştır. Katılımcıların çoğunluğunda batı ülkelerinin sağlık turizminden daha fazla pay aldığı düşüncesi bulunmaktadır. Bunun sebebi olarak akademisyenlerin pazarlama faaliyetlerinde $A B D$ ve $A B$ 
gibi gelişmiş ülkeleri öncü görmeleri ve Asya pazarının potansiyelinin ve pazarda yapılan faaliyetleri gözden kaçırdığı düşünülmektedir.

"Sağllk turizmi açısından Türkiye'yi nasıl değerlendiriyorsunuz" sorusuna ise katılımcılar Türkiye' de yüksek bir sağllk turizm potansiyeli olduğunu, özellikle medikal anlamda başarılı bir ülke olduğunu ve termal anlamda güçlü kaynakların bulunduğunu ancak tam anlamılla mevcut potansiyelin değerlendirilemediğini dile getirmişlerdir. Katılımcıların değerlendirmelerinin ülke istatistiki verilerine de yansıdığı görülmektedir. Başta organ nakilleri vd. cerrahi tedavilerin Türkiye'de başarılı bir şekilde yürütülüyor olması ve termal kaynak bakımından dünyada 7 . sırada yer alması var olan ülke potansiyelini göstermekte yardımcı olmaktadır.

“Sağlık turizminde rakip ülkelerle değerlendirildiğinde Türkiye'nin avantajı olarak gördüğünüz rekabet unsurları nelerdir?" sorusuna ise katılımclar genel olarak Türkiye'nin ekonomik bir pazar olması cevabını vermişlerdir. Ayrıca ülkenin jeopolitik konumu, kaliteli hizmet sunumu, sağlık ekiplerinin ve donanımının olması, turistik çekiciliklerin varlı̆̆ı ve turizm kültürü, ulaşım imkânı, yeni hastanelerin yapılması ve teknoloji olarak değerlendirmişlerdir. Katılımcıların verdiği cevaplar, sağlık turizmi kapsamında yapılan çalışmalarda (Edinsel ve Adıgüzel, 2014; Özata vd., 2018; Baş, 2017) elde edilen bulgularla örtüşmektedir.

Katılımcılar "sağlık turizminde rakip ülkelerle değerlendirildiğinde dezavantajlı olduğu rekabet unsurları nelerdir" sorusuna ise pazarlama eksikliği, ülkenin imaj problemi, uluslararası deneyime sahip kalifiye eleman sıkıntısı, personelin yabancı dil sorunu ve örgütlenme eksikliği olarak belirtmişlerdir. Ayrıca K9 ve K12 sağlık turizminde faaliyet gösteren illerin İstanbul ve Ankara olarak algılanmasının ve iç bölgelere ulaşım imkânlarının kısıtlı olmasından dolayı bu bölgelerde var olan başta termal turizm olmak üzere sağlık turizm potansiyelinin değerlendirilememesi sorununu ortaya çıkardığını vurgulamışlardır. Bunu önlemek için de havayolu ulaşımında sefer sayılarının artırılması, gerekirse charter seferlerin konulması ve yüksek hızlı trenin bu bölgelerde de aktif olarak kullanılması gerektiğini belirtmişlerdir. Bu bağlamda katılımcıların, literatürde Türkiye' de sağlık turizmi üzerine yer alan çalışmalara (İçöz, 2009; Doğan, 2019) paralel konulara değinmiş olması bu alandaki eksikliklerin varlığını destekler niteliktedir.

Akademisyenler "Türkiye'de sağlık turizminde en fazla tercih edilen tedaviler nelerdir" sorusuna ise saç ekimi, estetik operasyonlar, organ nakilleri, cerrahi operasyonlar, diş ve implant tedavisi, başta içmeler olmak üzere termal kaynaklardan yararlanılarak gerçekleştirilen termal tedaviler ve göz tedavisi olduğunu belirtmişlerdir. Katılımcılar, turistlerin özellikle Arapların saç ekimi konusunda Türkiye'yi seçtikleri, Akdeniz Üniversitesinin gerçekleştirdiği başta yüz nakli olmak üzere ülkenin genelinin organ nakillerinde iyi olduğu ve yine diş tedavilerinin Avrupa ülkelerine kıyasla ucuz tedavi türü olmasından dolayı Türkiye'nin tercih edildiğini ifade etmişlerdir. Katılımcıların çoğunun konu ilgili okuma yapmadıklarını ifade etmesi, verdikleri bilgilerin son yıllarda sağlık turizmine yönelik haberlerinin güçlü iletişim kanalı sosyal medyada sıkça dile getiriliyor olmasından kaynakladığını ortaya koymaktadır.

Katılımcılara "son yıllarda Türkiye'de yapılan sağlık turizminin gelişimine yönelik çalışmalar (10. kalkınma planı, Sağlık Turizmi tanıtım protokolü) hakkında ne düşünüyorsunuz" sorusu sorulmuş ve katılımcıların çoğunluğu bilgisinin olmadığını ifade etmiştir. K10, K11 ve K14 kalkınma planlarında sağlık turizmine yer verilmesinin önemli bir adım olduğunu, K18 konu hakkında mevzuat eksikliği olduğunu, K5, K7 ve K19 çalışmalar yapıldığını ancak uygulama noktasına gelindiğinde uygulanmadığı vurgulamışlardır. Katılımcıların çoğunluğu "sağlık turizminin gelişimi için kurulan Saturk ve Sağlık Turizm Daire başkanlığının çalışmaları hakkında ne düşünüyorsunuz?" sorusuna ise bilgim yok cevabını verirken, gelişmelerden haberi olan katılımcılar bu kuruluşların amaçlarının iyi olduğunu ancak faaliyetleri hakkında bilgisinin 
olmadığını ifade etmişlerdir. Bu konuda K11, Sağlık Turizm Daire Başkanlığının sağlık turizmi üzerine veri toplamakta yetersiz kaldığı, araştırmacılar için istenilen düzeyde veri yayınlamadığını dile getirmiştir. Sağlık turizminin gelişimi için atılan adımların katılımcılar tarafından bilinirliğinin az olması hem bu adımların tanıtımına yönelik eksiklikten kaynaklanabileceği hem de katılımcıların konuya tam hakimiyet kurmamalarından ötürü olabileceği düşünülmektedir.

“Sağlık turizminde başta Sağlık Bakanlığı ile Kültür ve Turizm Bakanlığı olmak üzere ilgili diğer bakanlıkların çalışmalarını nasıl buluyorsunuz" sorusuna ise katılımcılar kurumlar arasında işbirliğinin olmadığını düşündüklerini belirtmişlerdir. Bu sebeple kaliteli vizyon etrafında doğrudan ve dolaylı olarak işbirliği halinde olmaları gerektiğini vurgulamışlardır. Ayrıca K10, K12, K14, bakanlıklar arası veya tüm paydaşların dâhil edildiği bir komisyon kurulması gerektiğini; K13, Kültür Turizm Bakanlığının (KTB) sağlık turizmine senkronize çalışamayacağını bu yüzden Sağlık Bakanlığı ile ortak komisyon kurulması gerektiğini ve K15, KTB'nin sağlık turizmine desteğinin az olduğunu Sağlık Bakanlığının önerileri doğrultusunda kendi bünyesinde bir birim kurulması gerektiğini, K19 ise konu üzerinde ne kadar az bakanlık çalışırsa o kadar iyi olduğunu ve gerekirse ilgili birimlerin yetkilerine sahip ortak bir birim kurulabileceğini dile getirmiştir. Sağlık Turizminin Geliştirilmesi Programı Eylem Planı (2015)'na göre sorumlu kurum ve kuruluşlarda SB ve KTB'nin olduğu ancak KTB'nin sağlık turizmi alanında etkin tanıtım, pazarlama yapılması ve uluslararası işbirliğinin artırılması bileşeni ile sınırlandırılması katılımcıların değerlendirmeleri ile örtüşmektedir.

Katılımcılar "Türkiye'nin sağlık turizmi konusunda yaptığı pazarlama faaliyetleri (tanıtım vd.) hakkında ne düşünüyorsunuz?" sorusuna yapılan pazarlama faaliyetlerinin yetersiz olduğunu ifade etmişlerdir. Bu kapsamda K1, K4, K10, K11, K13 pazarlama faaliyetlerinin genel turizm dahilinde yapıldığını ve sağlık turizminin ihmal edildiği yönünde görüş bildirirken; $K 8$, K9, K13, K14, K16 ve K19 pazarlama faaliyetlerinde özel sektörün bireysel olarak çalışmalar yürüttügüüü kamunun bu alanda yetersiz kaldığını ve daha fazla sorumluluk alması gerektiğini; K5, K9, K15 ve K18 pazarlama yetersizliğini aşmak için hedef pazarlara yönelik pazarlama stratejilerine ihtiyaç olduğu ve günümüz iletişim araçlarından etkin olarak yararlanılması gerektiğini vurgulamışlardır. Pazarlama faaliyetlerinin sağlık turizminin gelişimine etkisi yadsınamayacak kadar büyüktür (Aktepe, 2013: 183). Bu bağlamda katılımcıların vurguladığı pazarlama faaliyetlerinin yetersizliği, pazar mücadelesinde Türkiye'ye fırsat kaybı riski oluşturabilecektir. Nitekim Dünya sağlık turizmi pazarında Türkiye'nin ilk on ülke içinde yer almaması yetersiz pazarlama faaliyetlerinden kaynaklandığı ifade edilebilmektedir.

"Sağlık turizminde Türkiye'nin sigortacılık işlemleri ile ilgili desteklemeler hakkında ne düşünüyorsunuz?" sorusuna katılımcıların çoğu herhangi bir bilgim yok ancak böyle bir destekleme sağlık turizminin gelişmesine yardımcı olacaktır cevabını vermişlerdir. K12 ve K13 özel hastanelerin yurtdışı sigorta şirketleri ile anlaşma halinde olduğunu ve kamunun yine bu alanda yetersiz kaldığını; K6 ve K19 ülkenin genel sağlık sigorta sisteminin iyi olduğunu belirtmişlerdir.

Görüşmenin devamında katılımcılara "sağlık turizminde kalite göstergeleri hakkında herhangi bir bilgiye sahip misiniz?" sorusu yöneltilmiş ve K3, K7, K8, K12, K13, K14, K15, K16, K17, K18 ve K19 bilgim yok olarak cevaplandırmıştır. K1 kalite göstergeleri olarak güvenilirlik, koordinasyon, faaliyetleri gerçekleştirme inanc1, performans, kullanıma uygunluk ve sıfır hata düzeyinde standartların oluşturulması olarak sıralama yaparken; K2, K4, K6 ve K11 hastanelerin almış olduğu akreditasyon belgelerini bildiklerini; K10, TURQUALITTY'nin sağllk kuruluşları da dahil bazı kuruluşlara kalite belgesi verdiğini ve yine ISO'nun bu alanda verdiği belgeleri olabileceğini söylerken; K11, akreditasyon belgelerinin yanında ISO'nun hastanelere yönelik 
kalite belgesi verdiğini ve sağlık bakanlığının hastanelere verdiği sağlık turizmi yetki belgesini bildiğini belirtmiştir.

K19: "bilgim yok ama en iyi gösterge hastanin yeniden hastaneye gelmemesi ya da tedavi sürecinin olabildiğince minimuma indirilmesidir" olarak cevaplandırmıştır. Sağlık sektöründe bakım güvenliği, hizmet kalitesi gibi standartların sağlanması ile hasta ve çalışanların maruz kalabileceği riskleri azaltmak amacıyla kurulan kurumlardan başta JCI olmak üzere çeşitli akreditasyon kurumlarının varlığı ve Türkiye'de pek çok sağlık kuruluşunun bu belgeye sahip olduğu bilgisi katılımcıların konu hakkında farkındalıklarının yetersiz olduğu söylenebilmektedir.

“Türkiye'de sağlık turizminin geliştirilmesi ve diğer ülkeler arasında hak ettiği yeri alabilmesi için ne tür çalışmalar yapılmalıdır?" sorusuna verilen cevaplar ise çeşitlilik arz etmektedir. Katılımclar bu soruda ortak bir cevap vermemiş ve farklı bakış açılarını ortaya koymuşlardır. Buna göre; K1, K6, K7 ve K10 organizasyonel yapılanma ve sektörel paydaşların etkinliğinin gerekliliğini bunun içinde büyük bir platform kurulması ve organizasyona ihtiyaç olduğunu; K2, merdiven altı sorununun çözülmesi ve seyahat acentalarının sağlık turizmi üzerine yürütülen çalışmalara daha etkin katılması gerektiğini; K3, medikal anlamda gösterilen başarının wellnessta da sağlanması gerektiğini söylemiştir. K4, K5, K8, K9 ve K16 pazarlama faaliyetlerinin artırılması, tanıtım ayağına odaklanılması ve bu alanda markalaşmanın sağlanması gerektiğini vurgulamışlardır. K12 ise kaynak dağılımında etkinlik sağlanması gerektiğini ve gelecekteki sağlık turizm talebini karşılayabilecek hastanelerin ve uzman personelin yetiştirilmesi gerektiğini söylemiştir. K13, sağlık turizminde ilerleme kaydetmek için turizmde daha fazla gelişme sağlanması gerektiğini, K15 tüm paydaşların katıldığı bir platformun yanında Türkiye'de bulunan her bölgede sağlık turizmi yerel yönetim merkezlerinin kurulması ve ilgili kurum ve kuruluşlarla işbirliğinin sağlanması gerektiğini belirtmişlerdir. K17 ve K19 kaliteli hizmet sunumunun yaygınlaştırılması ve devamlılığı sağlanarak ağızdan ağıza iletişim yoluyla sağlık turistlerine erişilebilirliğin artırılabileceğini vurgulamışlardır.

“Türkiye' de sağlık turizmin geliştirilmesi konusunda önerileriniz varsa lütfen belirtiniz?" olarak yöneltilen soruya katılımcilar mevcut eksikliklerin giderildiğinde sahip olunan sağlık turizmi potansiyelinin değerlendirileceğini belirtmişlerdir. Ayrıca K1 bu konuda turizm fakültelerinde sağlık turizmi derslerinin konulması gerektiğini, K6 sağlık turizminde farklı kılan özelliğin bulunup ona yönelik çalışmalar yapılması gerektiğini söylemiştir. K8, K12, K17 ve K18 sağlık turizminin yanında diğer turizm faaliyetlerine odaklanılması gerektiğini ve gelen sağlık turistinin aldığı tedavinin yanında diğer turistik hizmetlerden de yararlanmasını sağlayarak hem eğlenme hem de tedavi olabilecekleri bir ortam oluşturulması ve daha fazla turizm geliri kazanılması gerektiğini vurgulamışlardır. K10 sağlık turizminin e-ticaret konseptine aktarılmasının avantaj doğuracağını ifade ederken;

K15: "Türkiye'de her bölgede sağlık turizmi ile açık hava müzesi oluşturulabilir. Turistlerin çok ziyaret ettiği bir tesisi bölgedeki sağllk turizmi değerlerini gösteren minyatürler veya kapalı bir bölümde sağllk turizm ile ilgili o bölgeyi anlatan dev ekranlarla bir tanıtım odası kurulabilir ya da İstanbul havalimanında bir bölümde sağllk turizmi ile ilgili tüm Türkiye'ye ait sağllk turizm bilgileri, illerin tanıtımı faaliyetlerin gösterilmesi, uygulanan her şeyin turistlerin elinin altında onlara hitap edecek şekilde sunulması gerekir." şeklinde belirtmiştir."

K18: "son çalışmaları bilmiyorum fakat sağlık turizmi ile ilgili yapılan çalışmalar kamuoyuna yansımıyor bu alan bir deniz turizmi gibi işlenmesi gerekir. Konu gündeme gelmiyor sorun var burada. Ayrica hastanelerin aldıkları yetki belgesinde birç̧ok sıkıntılar var; iş burada ticarete dönüyor bir alışverişe dönüyor. Sağllk turizminde sadece otel ya da sadece hastane yetmez gelen sağllk turisti aldiğ tedavinin yanında programlar ile diğer turizm türlerine entegre olmalıdır. Mesela hastane să̆llk turistini getirdim- 
götürdüm işine dönüşürse olay kapalı bir kutu halini alır. Herkes kendisine göre çalışmaya başlar bu durumda. Amaç burada sağllk turistlerine bir program yaptırmaktır. Ayrıca turistin vize işlemleri, transferinin ve rehberlik işlemlerinin yapılması, yöresel yöreleri değerlendirme üzerine odaklanılmalı sadece hastane odaklı düşünmeden kaçınılmal. Sağhlk turizminin çeşitlerinde sadece hastane değil diğerlerine odaklanılmal." şeklinde belirtmiştir.

K19: "En büyük sıkıntı insan kalitesi. "Kültür stratejiyi kahvaltıda yer" dolayısıyla insan kültürünü, insan kalitesini artırmak gerek. Neyi geliştireceksek eğitimle önce insan kalitesini artırmalıyız sonra o işte başarı sağlanabilir. Bir diğer yandan sağllk personeline yönelik yapılan saldırılar personelin hizmet verimliliğini azaltıyor. Çünkü hasta olan biliyor ne çektiğgini. Yani yine başa dönüyoruz insan kalitesinin artırılması ile her alanda yükselebiliriz." şeklinde ifade etmiştir.

\section{TARTIŞMA, SONUÇ VE ÖNERILER}

Son yıllarda tedavi ve tatil amaçlı seyahatlerin artmasıyla önemi giderek artan sağlık turizmi, birçok ülkede tercih edilen turizm çeşididir. Kaynaklarının farklılı̆̆ı ve sağlık sorunlarını çözerek hastanın iyileştirilmesinde yardımcı tedavi türlerine ayrılan sağlık turizmi dünya turizminde son yıllarda popüler bir hale gelmiştir. Türkiye'de özellikle 2000'li yıllardan itibaren sağlık turizminde önemli bir pay sahibi olmaya başlamıştır. Bu çalışma Türkiye'de sağlık turizminin, turizm fakültesinde görevli 19 akademisyen tarafından değerlendirilmesi amaciyla gerçekleştirilmiştir. Bu kapsamda akademisyenler ile yarı yapılandırılmış görüşme formu vasıtasıyla görüşmeler yapılmıştır. Elde edilen bulgulara göre akademisyenlerin görev yaptığ üniversitelerde sağlık turizmi adı ile ders verilmediği sonucuna ulaşılmıştır. Buradan Türkiye'de sağlık turizminde turizm kaynaklı istihdam fikrinin kısmen de olsa ihmal edildiği değerlendirilebilmektedir. Akademisyenler, Dünya sağlık turizm destinasyonu sıralamalarında genellikle gelişmiş ülkelere (Avrupa ve $A B D$ ) yer verdikleri belirlenmiştir. Ancak akademisyenlerin sağlık turizmi pazarında esas pazar payına sahip Asya ülkelerini gözden kaçırdıkları tespit edilmiştir. Katılımcılar Türkiye'yi sağlık turizmi açısından değerlendirdiklerinde, ülkenin sahip olduğu sağlık turizm potansiyelinin farkındalıkları ön plana çıkmaktadır. Ayrıca katılımcılar Türkiye'nin jeopolitik konumu, kaliteli hizmet sunumu, sağlık ekiplerinin ve donanımının olması, turistik çekiciliklerin varlığı, turizm kültürünün olması, ulaşım imkânı, yeni hastanelerin yapılması ve teknolojisinin bulunmasının sağlık turizminde bir avantaj olduğunu belirtmişlerdir. Dezavantaj olarak ise pazarlama eksikliği, ülkenin imaj problemi, uluslararası deneyime sahip kalifiye eleman sıkıntısı, personelin yabancı dil sorunu ve örgütlenme eksikliği açısından bir değerlendirme yaptıkları görülmektedir. Türkiye'de sağlık turizminde en fazla tercih edilen tedaviler katılımcılar tarafından saç ekimi, estetik operasyonlar, organ nakilleri, cerrahi operasyonlar, diş ve implant tedavisi, başta içmeler olmak üzere termal kaynaklardan yararlanılarak gerçekleştirilen termal tedaviler olarak sıralanmıştır. Uygulanan tedavi türlerinde başta saç ekimi, estetik ve cerrahi operasyon olmak üzere medikal turizmin ağırlığını hissettikleri gözlenmiştir.

Katılımcılardan Türkiye'de sağlık turizminin gelişimine yönelik geliştirilen plan ve protokol ve kurulan kurum ve kuruluşlar hakkında görüş bildirmeleri istenildiğinde katılımcıların yapılan faaliyetler hakkında detaylı bilgi sahibi olmadıkları belirlenmiştir. Bu durumun turizm perspektifinde değerlendirildiğinde eğitim, sektör ve bürokrasi üçlüsü arasında iletişim eksikliğinin bir sonucu olarak ortaya çıktığı düşünülmektedir. Ayrıca katılımcılar kurulan daire başkanlıklarının veri toplama ve yayınlama açısından istenilen düzeyde olmadığını belirtmişlerdir. Sağlık Bakanlığı'nın bu konu ile ilgili detaylı çalışmalar yürütmesi hem bu alanda akademik çalışmaların sayısını ve niteliğini artıracak hem de sağlık turistlerinin geleceği ülkenin sağlık turizmi geçmişini öğrenmesini sağlayarak sağlık turistine bilgi akışı ve güven 
sağlanacaktır. Akademisyenler bakanlıkların sağlık turizmi üzerine çalışmalarında işbirliği yapmaları beklentisi içinde oldukları, sağlık turizminde yürütülen pazarlama faaliyetlerinde Türkiye'nin istenilen düzeyin altında çalışmalar gösterdiğini, sigortacılık desteklemeleri ile ilgili bilgi düzeylerinin düşük olduğu sonucuna erişilmiştir. Katılımcıların sağlık turizminde kalite göstergeleri hakkında görüşleri incelendiğinde birçoğunun kalite göstergeleri hakkında bilgisinin olmadığı sonucuna ulaşılmıştır. Bunun nedeni sadece yurtdışında kabul görmüş kalite belgelerinin yeterli görülmesi ve ülke olarak ortak kriterlere sahip olunmaması şeklinde ifade edilebilmektedir. Ayrıca bakanlık düzeyinde yapılacak standart çalışmalara turizm akademisyenlerinin de dahil edilmesi çalışmalara katma değer sağlayacaktır. Sağlık turizminin geliştirilmesi yönünde yapılması gereken çalışmalar konusunda ise katılımcılar, pazarlama ve tanıtım, markalaşma, uzman personel ve kaliteli hizmet sunulması gibi farklılık arz eden cevaplar verdikleri görülmüştür. Katılımcılardan sağlık turizminin geliştirilmesi için öneri getirmesi istenildiğinde, turizm öğrencilerinin sağlık turizm farkındalığını artırmak ve sağlık turizminin eticaret konseptine aktarılmasının avantaj sağlayacağını vurgulamışlardır.

Çalışma genel olarak ele alındığında, akademisyenlerinin sağlık turizmi üzerine kısmen yeterliliğe sahip oldukları sonucuna erişilmiştir. Sağlık turizmi paydaşı olarak sektörün gelişimine yardımcı olabilecek akademisyenlerin sayısının artması eğitim-turizm-ekonomi üçlüsüne olumlu katkı sağlayacaktır. Ayrıca çalışma ile katılımcı akademisyenlerin sağlık turizminde başta avantaj veya dezavantaj olarak gördükleri durumlar ve yapılan çalışmaları değerlendirmeleri ileride bu alanda yürütülecek plan ve politikalarda kısmen yol gösterici olması beklenmektedir.

\section{KAYNAKÇA}

Aba, G., Gümüş, J. ve Çakır, N. (2019). Sağlık Çalışanlarının Medikal Turizme Yönelik Algılarının İncelenmesi: Özel Hastane Örneği, Yönetim ve Ekonomi Araştırmaları Dergisi, 17(3): 93-105.

Acar, N. ve Turan, A. (2016). Sağlık Çalışanlarının Sağlık Turizmi Farkındalığı Üzerine Bir Araştırma: Ahi Evran Üniversitesi Eğitim ve Araştırma Hastanesi Çalışanları Örneği, Cumhuriyet Üniversitesi İktisadi ve İdari Bilimler Dergisi, 17(1). 17-36.

Akbolat, M. ve Deniz, N. G. (2017). Türkiye'de Medikal Turizmin Gelişimi ve Bazı Ülkelerle Karşılaştırılması, Uluslararası Global Araştırmaları Dergisi, 1(2): 123-139.

Aksu, A., Şeker, F. and Unur, K. (2017). Health Tourism and the Present Status in Turkey, (Editör) Efe, R., Penkova, R., Wendt, J. A., Saparov, K. T. ve Berdenov, J. G.: Developments in Social Sciences içinde (ss.523-532) Sofia: ST. Kliment Ohridski University Press.

Aktepe, C. (2013). Sağllk Turizminde Yeni Fırsatlar ve Türkiye'de Yerleşik Sağllk İşletmelerinin Pazarlama Çabaları, İşletme Araştırmaları Dergisi, 5(1): 170-188.

Altın, U., Bektaş, G., Antep, Z. ve İrban, A. (2012). Sağlık Turizmi ve Uluslararası Hastalar İçin Türkiye Pazarı, Acıbadem Üniversitesi Sağlık Bilimleri Dergisi, 3(3): 157-163.

Altsoy, S. (2018). Sağlık Turizmi Alanında Faaliyet Gösteren Hastanelerdeki Mevcut Sorunlar ve Çözüm Önerileri, Yayımlanmamış Yüksek Lisans Tezi, Trakya Üniversitesi, Edirne.

Arslan, E. (2018). Sağglık Turizminde Türkiye'nin Son 5 Yılda Dünya Ülkeleri İçindeki Konumu ve Gelişmesi, Yayınlanmamış Yüksek Lisans Tezi, Bahçeşehir Üniversitesi, İstanbul.

Ataman, H., Esen, M. F. ve Vatan, A. (2017). Medikal Turizm Kapsaminda Sunulan Hizmetlerinde Kalite ve Hasta Güvenliği, Uluslararası Sağ lık Yönetimi ve Stratejileri Araştırma Dergisi, 3(1): 28-44. 
Aydın, G. ve Aydın, B. K. (2015). Dünya'da ve Türkiye'de Sağlık Turizmi Pazarlama Uygulamaları ve Karşılaştırmalı Durum Analizi, Pazarlama ve Pazarlama Araştırmaları Dergisi, 16, $1-21$.

Aydın, G. and Karamehmet, B. (2017). Factors Affecting Health Tourism and International Healthcare Facility Choice, International Journal of Pharmaceutical and Healthcare Marketing, 11(1): 16-36.

Aydın, O. (2012). Türkiye'de Alternatif Bir Turizm: Sağlık Turizmi, KMÜ Sosyal ve Ekonomik Araştırmalar Dergisi, 14(23): 91-96.

Baş, İ. (2017). Türk Turizminin Dünyadaki Güçlü Rolü ve Sağlık Turizmine Etkisi, Uluslararası Hakemli Pazarlama ve Pazar Araştırmaları Dergisi, 11: 49-68.

Batı Akdeniz Kalkınma Ajansı. (2013). Sağlı Turizmi Sektör Raporu. https://baka.gov.tr/dokuman-merkezi/dokumanlar/sektor-raporlari/saglik-turizmi-sektorraporu [Erişim Tarihi: 15.10.201].

Barca, M., Akdeve, E. ve Balay, İ. G. (2013). Türkiye Sağlık Turizm Sektörünün Analizi ve Strateji Önerileri, İ̧sletme Araştırmaları Dergisi, 5(3): 64-92.

Basa, E. (2017). Sağllk Turizmi, Şehir Hastaneleri ve Sağlık Serbest Bölgeleri, Toplum ve Hekim, 32(4): 275-281.

Bayar, K. (2019). Dünya'da ve Türkiye'de Sağlık Turizminin Önemi ve Gelişimi: Antalya Yöresi Araştırması, Yayınlanmamış Yüksek Lisans Tezi, Akdeniz Üniversitesi, Antalya.

Baysal, D. (2016). The Contribution of Health Tourism to Turkish Tourism Income: 2000-2015, Balkan Sosyal Bilimler Dergisi, Aralık: 250-261.

Becheri, E. (1989). From Thermalism to Health Tourism, The Tourist Review, 44(4): 15-19.

Blazevic, O. (2016). Health Tourism and Smart Specialisation, UTMS Journal of Economics, 7(1), 8595.

Breitrück, V. and Nunn, E. (2011). The Long Tail of Tourism. Wiesbaden: Gabler.

Buzcu, Z. ve Birdir, K. (2019). Türkiye'de Medikal Turizm İncelemesi: Özel Hastanelerde Bir Çalışma, Gaziantep University Journal of Social Sciences, 18(1): 311-327.

Canver, Ş. S. (2015). Kamu ve Özel Hastane Çalışanlarının Sağllk Turizmine İlişkin Algılarının Değerlendirilmesi, Yayımlanmamış Yüksek Lisans Tezi, Okan Üniversitesi, İstanbul.

Cochrane, J. (2008). Asian Tourism: Growth and Change (Advances in Tourism Research), Amsterdam: Elsevier.

Çılgınoğlu, H. (2018). Uluslararası Sağlık Turizminin Ekonomik, Hukuki ve İdari Yönden Değerlendirilmesi: Türkiye'deki Hastaneler Üzerinde Örnekleme, Yayınlanmamış Doktora Tezi, Kastamonu Üniversitesi, Kastamonu.

Çimen, H. (2018). Türk Dünyasında Sağlık Turizmi, Karadeniz Uluslararası Bilimsel Dergi, 40, 101110.

Dedeoğlu, A. K. (2018). Sağllk Turizmi Yapan Gelişmekte Olan Ülkelerde Kaynakların Adil Dağıtımı Problemi, Journal of Social Sciences and Humanities, 2(2): 86-93.

Deloitte. (2018). Health \& Wellness Progress Report. Deloitte Touche Tohmatsu Limited. https://www2.deloitte.com/content/dam/Deloitte/au/Documents/consumer-industrial- 
products/deloitte-au-health-wellness-progress-report-2018-120319.pdf [Erişim Tarihi: 08.11.2019].

Doğan, E. (2019). Dünya Sağlık Turizminde Türkiye'nin Yeri ve Ekonomiye Katkısı, Yayınlanmamış Yüksek Lisans Tezi, Beykent Üniversitesi, İstanbul.

Edinsel, S. ve Adıgüzel, O. (2014). Türkiye'nin Sağlık Turizmi Açısından Son Beş Yıldaki Dünya Ülkeleri İçindeki Konumu ve Gelişmeleri, Çankırı Karatekin Üniversitesi İktisadi ve İdari Bilimler Dergisi, 4(2): 167-190.

European Parliament. (2017). Research for TRAN Committee-Health Tourism In The EU: A General Investigation. Directorate-General for Internal Policies. European Parliament, Directorate-General for Internal Policies, Policy Department. https://www.europarl.europa.eu/RegData/etudes/STUD/2017/601985/IPOL_STU(2017)601985_E N.pdf [Erişim Tarihi: 29.10.2019].

García-Altés, A. (2005). The Development of Health Tourism Services, Annals of Tourism Research, 32(1): 262-266.

Göçer, İ. ve Aydın, N. (2016). Türkiye'de Sağlık Değişkenlerinin Turizm Gelirine Etkisi: Çoklu Yapısal Kırılmalı Bir Analiz, Çankırı Karatekin Üniversitesi İktisadi ve İdari Bilimler Fakültesi Dergisi, 6(1): 777-800.

Görener, A. (2016). A SWOT-AHP Approach for Assessment of Medical Tourism Sector in Turkey. The Journal of Operations Research, Statistics, Econometrics and Management Information Systems, 4(2): 159-170.

Gülmez, Z. (2012). Türkiye'de ve Dünya'da Sağhlk Turizmi ve Çeşitleri: Sağlık Turizminin Ülkemizdeki Mevcut Durumu ve Bazı Ülkelerle Kıyaslanması, Yayınlanmamış Yüksek Lisans Tezi, İstanbul Üniversitesi, İstanbul.

Hofer, S., Honegger, F. and Hubeli, J. (2012). Health Tourism: Definition Focused on The Swiss Market and Conceptualisation of Health(I)Ness, Journal of Health Organization and Management, 26(1): 60-80.

https://www.medicaltourism.com/compare-prices [Erişim Tarihi: 09.01.2020].

http://www.saglik.gov.tr/TR,11588/istatistik-yilliklari.html [Erişim Tarihi: 06.11.2019].

http://www.saglik.gov.tr [Erişim Tarihi: 06.11.2019].

http://www.saglikturizmi.saglik.gov.tr/ [Erişim Tarihi: 16.10.2019].

http://www.saturk.gov.tr/ [Erişim Tarihi: 16.10.2019].

http://www.tuik.gov.tr_[Erişim Tarihi: 06.11.2019].

İçöz, O. (2009). Sağlık Turizmi Kapsamında Medikal (Tıbbi) Turizm ve Türkiye'nin Olanakları, Journal of Yasar University, 4(14): 2257-2279.

Jònàs-Berki, M., János C., Andrea P. and Antal, A. (2015). A Market and Spatial Perspective of Health Tourism Destinations: The Hungarian Experience. International Journal of Tourism Research, 17: 602-612.

Kızıldağ, G. Ç. (2018). Hekim Dışı Sağlık Personeli ve Sağlık Yöneticilerinin Medikal Sağlık Turizmi Konusunda Farkındalıklarının Değerlendirilmesi, Yayımlanmamış Yüksek Lisans Tezi, Ufuk Üniversitesi, Ankara. 
Koncul, N. (2012). Welness: A New Model of Tourism, Economic Research-Ekonomska İstraživanja, 25(2): 525-534.

Lee, C. G. (2010). Health Care and Tourism: Evidence from Singapore, Tourism Management, 31(4): 486-488.

Loh, C. A. (2014). Health Tourism on The Rise? Evidence from The Balance of Payments Statistics, The European Journal of Health Economics, 15(7): 759-766.

Medical Tourism Magazine. (2019). www.medicaltourismmag.com [Erişim Tarihi: 05.10.2019].

Öncü, M. A., Çatı, K. ve Yalman, F. (2016). Medikal Turizm Kapsamında Gelen Yabancı Hastalar ile Yerli Hastaların Memnuniyet ve Sadakatlerinin Karşılaştırılması, Bartın Üniversitesi İktisadi ve İdari Bilimler Fakültesi Dergisi, 7(14): 45-72.

Özata, M., Asilkan, Z., Çankaya, M. ve Suzuk, E. (2018). Türkiye ve Dünya'da Sağlık Turizmine Genel Bir Bakış, Journal of Social and Humanities Sciences Research, 5(31), 4611-4619.

Özcan, K. ve Aydın, V. (2015). Sağlık Turizmi (Teori ve Politika). Kocaeli: Umuttepe Yayınları.

Özkurt, H. (2007). Sağlık Turizmi Tahvilleri, Maliye Dergisi, 152, Ocak-Haziran, 121-142.

Öztürk, M. ve Bayat, M. (2011). Uluslararası Turizm Hareketlerinde Sağlık Turizminin Rolü ve Kalite Çalışmalarının Önemi Bir Literatür Çalışması, Kahramanmaraş Sütçü İmam Üniversitesi Iktisadi ve İdari Bilimler Fakültesi Dergisi, 1(2): 135-156.

Rieger, T. (2013). Sustainability in Tourism, (Editör) Jenkins, I. and Schröder R.: $A$ Multidisciplinary Approach içinde (ss. 53-68) Wiesbaden: Springer.

Ross, K. (2001). Health Tourism: An Overview, HSMAI Marketing Review.

Smith, P. C. and Forgine, D. A. (2007). Global of Healthcare: A Medical Tourism Decision Model, Journal of Information Technology Case and Application Research, 9(3): 19-30.

Sülkü, N. S. (2017). Sağlık Turizminde Türkiye'nin Dünyadaki Yeri ve Potansiyeli. Uluslararası İktisadi ve İdari Bilimler Dergisi, Özel Sayı 1: 99-113.

Şahbaz, R. P., Akdu, U. ve Akdu, S. (2012). Türkiye'de Medikal Turizm Uygulamaları; İstanbul ve Ankara Örneği, Balıkesir Üniversitesi Sosyal Bilimler Enstitüsü Dergisi, 15(27): 267-296.

Şahin, Ö. U. ve Şahin, M. (2018). Türkiye'de Sağllk Turizminin Potansiyeli ve Geleceği: SWOT Analizi. Journal of Awareness, Özel Sayı 3: 287-300.

T. C. Sağlık Bakanlığı. (2019). 2018 Veri Kayıtları, [15.11.2019, 14.01.2020 tarihinde alınmıştır].

Temizkan, S. P. (2015). Sağ lık Turizmi. Ankara: Detay Yayıncılık.

Tontuş, H. Ö. (2018). Sağlık Turizmi Tanıtımı ve Sağlık Hizmetlerinin Pazarlanması İlkeleri Üzerine Değerlendirme, Disiplinlerarası Akademik Turizm Dergisi, 3(1), 67-88.

Tür, Ş. (2015). Health Tourism and Regulation for Social Security Applications, Journal of Social and Administrative Sciences, 2(1): 3-10.

Türnüklü, A. (2000). Eğitimbilim Araştırmalarında Etkin Olarak Kullanılabilecek Nitel Bir Araştırma Tekniği: Görüşme, Kuram ve Uygulamada Eğitim Yönetimi, 24: 543-559.

Tütüncü, Ö., Kiremitçi, İ. ve Çalışkan, U. (2011). Sağlık Turizmi, Güvenlik ve Kalite, Anatolia: Turizm Araştırmaları Dergisi, 22(1): 91-93.

Uçak, H. (2016). The Relationship Between the Growth in The Health Sector and Inbound Health Tourism: The Case of Turkey, Springerplus, 5: 1-10. 
Uygun, M. and Ekiz, E. (2016). An Overview of Health Tourism Within the Context of Turkey's Tourism Strategy (2023), Journal of Hospitality and Tourism, 14(1): 18-26.

World Tourism Organization and European Travel Commission. (2018). Exploring Health TourismExecutive Summary, UNWTO, Madrid, doi: https://doi.org/10.18111/978928442030.8.

Yardan, E. D., Dikmetaş, H., Us, N. C. ve Yabana, B. (2014). Türkiye ve Dünya'da Sağlık Turizmi, Sağlık Performans ve Kalite Dergisi, 8: 27-42.

Yavuz, M. (2017). Küresel Kapitalizmin Tıbba Dokunuşu: Sağllk Turizmi, Toplum ve Hekim. 32(4): 245-253.

Yazan, T., Girgin, A. and Karadağ, E. (2017). Health Tourism in Turkey, (Editör) İsaxanli, H.: Khazar Journal of Humanities and Social Sciences içinde (ss.196-208) Bakü: Khazar Üniversitesi Yayınları.

Yiğit, V. (2016). Kamu Hastanelerinde Medikal Turizminin Gelişiminin Etkileyen Faktörler, Süleyman Demirel Üniversitesi Vizyoner Dergisi, 7(15): 107-119.

Yorulmaz, M. (2019). An Overview of Health Tourism, (Editör) Meciar, M., Gökten, K. ve Eren, A. A.: Economic and Business Issues in Retrospect and Prospect içinde (ss.343-354) London: IJOPEC Publication Limited.

Zengingönül, O., Emeç, H., İyilikçi, D. E. ve Bingöl, P. (2012). Sağllk Turizmi: İstanbul'a Yönelik Bir Değerlendirme, İstanbul Kalkınma Ajansı, Ekonomistler Platformu. 